\title{
O REGIME JURÍDICO DAS EMPRESAS ESTATAIS SOB A ÓTICA DA LEI N.13.303/2016: ASPECTOS GERAIS, ESPECÍFICOS E POLÊMICOS
}

\author{
Gabriel Senra da Cunha Pereira ${ }^{1}$ \\ Edimur Ferreira de Faria ${ }^{2}$
}

\section{RESUMO}

Este trabalho tem por objetivo identificar o regime jurídico estabelecido pela Lei n. 13.303, de 30.06.2016. Primeiramente se fará breve histórico da evolução normativa relacionada às empresas estatais. Em seguida, examinar-se-á a abrangência da lei em referência. $\mathrm{O}$ exame do regime jurídico aplicável será feito a partir da análise dos dispositivos que tratam da responsabilidade civil dos controladores, dos critérios para nomeação de diretores e membros do Conselho de Administração, e dos contratos relacionados às atividades-fim e atividadesmeio das empresas estatais. A metodologia da pesquisa consistirá na consulta bibliográfica, jurisprudencial e à legislação que abrange o tema.

Palavras-chave: Empresas Estatais; Regime Jurídico; Direito Público; Direito Privado; Abrangência; Responsabilidade civil; Licitações; Contratos.

\section{THE LEGAL REGIME OF GOVERNMENT-OWNED COMPANIES UNDER THE PERSPECTIVE OF LAW N. 13.303/2016: GENERAL, SPECIFIC AND CONTROVERSIAL ASPECTS}

\begin{abstract}
This work aims to identify he legal regime established by Law 13.303/2016. First, we will make a brief history of regulatory developments related to government-owned companies. Next, we will examine the amplitude of Law 13.303/2016. The examination of the applicable legal regime per se will be done by analyzing the provisions that deal with controllers' civil liability, the criteria for appointment of directors and members of the Board of Directors, and the contracts related to the essentials and non-essentials activities of the government-owned companies. The work methodology will consist of bibliographical consultation, case law and legislation covering the topic.
\end{abstract}

Keywords: Government-owned Companies; Legal Regime; Public Law; Private Law; Amplitude; Civil liability; Biddings; Contracts.

\footnotetext{
${ }^{1}$ Graduado em Direito pela Faculdade de Direito Milton Campos, pós-graduado latu sensu em Direito Processual pelo Instituto de Educação Continuada da PUC Minas, mestrando do Programa de Pós-Graduação em Direito da PUC Minas, advogado. Endereço eletrônico: gabriel@cunhapereira.adv.br. Endereço postal: Av. Joaquim José Diniz, n. 20, apto. 904, torre 01, bairro Fernão Dias, Belo Horizonte/MG, CEP 31.910-520.

${ }^{2}$ Mestre e doutor em Direito pela Universidade Federal de Minas Gerais, professor da Graduação e do Programa de Pós-Graduação em Direito da PUC Minas, Ex-Diretor da Faculdade Mineira de Direito, Ex-Diretor da Escola de Contas e Capacitação do Tribunal de Contas do Estado de Minas Gerais, Ex-Presidente do Instituto Mineiro de Direito Administrativo. Endereço eletrônico: edimurfaria@hotmail.com. Endereço postal: Rua Edeltônio Frota Cruz, n. 305, bairro Garças, Belo Horizonte/MG, CEP 31.545-050.
} 


\section{INTRODUÇÃO}

O regime jurídico das empresas estatais sempre foi tema de controvérsias no âmbito da doutrina e da jurisprudência. Antes da edição da Lei n. 8.666/1993 (BRASIL, 1993), as empresas públicas e sociedades de economia mista se submetiam, inicialmente, às normas do Decreto-Lei n. 200/1967 (BRASIL, 1967), o qual previa, no art. 27, parágrafo único, que o funcionamento delas se daria em condições idênticas às do setor privado. Em 1986, aludidas empresas estatais passaram a se submeter ao regime licitatório e de contratação estabelecidas pelo Decreto-Lei 2.300/1986 (BRASIL, 1986), e, a partir de junho de 1993, ao regime da Lei n. 8.666/1993 (BRASIL, 1993). Esta última regulamenta o inciso XXI, do art. 37 da Constituição da República Federativa do Brasil de 1988 (CRFB/1988) (BRASIL, 1988). Atualmente, as licitações e as contratações realizadas pelas empresas públicas e sociedades de economia mista e suas subsidiárias estão regidas pela Lei n. 13.303/2016 (BRASIL, 2016).

A CRFB/1988 estabelece que, ressalvados os casos nela previstos, "a exploração direta de atividade econômica pelo Estado só será permitida quando necessária ao imperativo da segurança nacional ou ao relevante interesse coletivo, conforme definidos em lei." (BRASIL, 1988). E que a atuação econômica nesses casos será por meio de empresas públicas e sociedades de economia mista, as quais se sujeitariam ao regime jurídico próprio das empresas privadas (art. 173, caput, e $\S 1^{\circ}$, II), com a redação conferida pela Emenda Constitucional (EC) n. 19/1998 (BRASIL, 1998).

Todavia, a mera indicação de que às empresas estatais se aplicaria o regime jurídico de Direito Privado não eliminou as inúmeras controvérsias acerca do alcance da referida determinação constitucional, principalmente no que se refere à obrigatoriedade ou não de elas se sujeitarem a um regime geral de licitações e contratações.

A Lei $n^{\circ} 8.666 / 1993$ (BRASIL 1993) aparentemente resolveria a controvérsia, ao estipular, no parágrafo único do art. $1^{\circ}$, que as empresas públicas e sociedades de economia mista se subordinariam integralmente às suas normas, sem distinção.

O comando legal, contudo, não trouxe solução à polêmica, pois submeteu as entidades estatais de Direito Privado, que atuam no campo de exploração de atividades econômicas, nos casos previstos na $\mathrm{CRFB} / 1988$, às mesmas condições e exigências a que se submetem as entidades de Direito Público. Assim, a subordinação das empresas estatais ao regime extremamente formal, rígido e rigoroso de licitações e contratações estabelecido pela Lei n. 8.666/1993 dificultaria a atuação empresas estatais em ambiente competitivo. 
Com o objetivo de excluir as empresas estatais da regência da Lei n. 8.666/1993, a Emenda Constitucional $n^{\circ}$ 19/1998 alterou o art. 22, inciso XXVII da CRFB/1988, para estabelecer que caberá à União legislar sobre normas gerais de licitações e contratações aplicáveis para a Administração Pública direta, autárquica e fundacional da União, Estados, Distrito Federal e Municípios, observado o disposto no art. 37, XXI. As empresas estatais, como se vê, foram excluídas desse comando constitucional.

O $\S 1^{\circ}$, do art. 173 da CRFB/1988, com a nova redação, atribuiu à lei ordinária dispor sobre o estatuto jurídico das empresas estatais, especificamente quanto à sujeição destas ao regime próprio de Direito Privado e a regras específicas para licitações e contratos, observados os princípios gerais da Administração Pública.

O referido estatuto jurídico das empresas estatais veio dezoito anos após a EC n. 19/1998, com a Lei n. 13.303/2016. Durante esse período, a doutrina e a jurisprudência oscilaram, ora entendendo que enquanto não for editada a lei dispondo sobre o referido estatuto jurídico as empresas públicas e sociedades de economia mista se sujeitariam ao regime geral de licitações, nos termos da Lei n. 8.666/1993, ora entendendo que elas, com fulcro no art. 173, § $1^{\circ}$ da CRFB/1988, mesmo na ausência do estatuto, poderiam editar regras próprias de licitações e contratações.

Para Mello (2015) as empresas estatais prestadoras de serviços públicos sempre seriam adstritas à Lei n. 8.666/1993, enquanto as exploradoras de atividade econômica continuariam seguindo os ditames dessa lei até a edição da norma regulamentadora do art. 173, $\S 1^{\circ}$, da CRFB/1988. O mesmo entendimento é compartilhado por Carvalho Filho (2015) e Di Pietro (2014).

O posicionamento de Faria (2015, p. 291) é no sentido de que, antes da edição da n. Lei 13.303/2016, “as empresas públicas e sociedades de economia mista continuam sujeitas às regras da Lei n. 8.666/93".

Meirelles (2014) admite que as estatais com personalidade jurídica de Direito Privado poderiam ter regulamentos próprios antes da Lei n. 13.303/2016, desde que sujeitos às normas gerais da lei de licitações.

A Lei n. 13.303/2016 encerrou a controvérsia e dispôs, no art. 41, que somente serão aplicadas às empresas estatais as normas de Direito Penal previstas na Lei n. 8.666/1993. Fora isso, aplica-se o que naquela contém.

O problema da presente pesquisa consiste nas seguintes indagações: o regime estabelecido pelo Estatuto Jurídico das Empresas Estatais é exclusivamente de Direito 
Privado? Ou recebe influências de Direito Público? E, na hipótese de o Estatuto contemplar os dois ramos do Direito mencionados, em que momento prevalece um ou o outro?

O objetivo do presente trabalho é, pois, examinar o regime jurídico das empresas estatais estabelecido pela Lei 13.303/2016, na tentativa de elucidar os pontos obscuros ou, em tese, conflitantes, e responder as perguntas contidas na problematização. Além de examinar a natureza jurídica da responsabilidade civil do controlador da empresa estatal, dos critérios de nomeação dos seus administradores, e das licitações e contratos celebrados pelas empresas públicas e sociedades de economia mista em face da Lei n. 13.303/2016 e da CRFB/1988, art. $37, \S 6^{\circ}$.

Utiliza-se metodologia exploratória de trabalho, consistente na consulta bibliográfica e jurisprudencial, bem como na análise das principais modificações introduzidas pelo novel diploma normativo em relação às normas de Direito Público e Privado existentes, como a Lei Geral de Licitações e Contratos (n. 8.666/1993), a Lei das S/A (n. 6.404/1976) (BRASIL, 1976) e o Código Civil de 2002 (BRASIL, 2002).

\section{A ABRANGÊNCIA DA LEI N. 13.303/2016}

A definição sobre a abrangência da Lei n.13.303/2016 é primordial. Conforme Oliveira (2016), “a distinção relativa ao objeto da estatal influencia decisivamente no respectivo regime licitatório. Enquanto a atividade econômica encontra-se submetida ao princípio da livre concorrência, a prestação do serviço público é de titularidade estatal." (OLIVEIRA, Rafael 2016).

$\mathrm{O}$ art. $1^{\circ}$ do Estatuto Jurídico das Empresas Estatais sujeita às suas normas as empresas públicas e sociedades de economia mista de qualquer dos entes federados que explorem "atividade econômica de produção ou comercialização de bens ou de prestação de serviços, ainda que a atividade econômica esteja sujeita ao regime de monopólio da União ou seja de prestação de serviços públicos”. (BRASIL, 2016).

O dispositivo classifica a "atividade econômica" como gênero, do qual são espécies a "produção ou comercialização de bens ou de prestação de serviços, ainda que em regime de monopólio" e a "prestação de serviços públicos", aderindo ao entendimento já evidenciado pelo Supremo Tribunal Federal no julgamento da ADPF no 46/DF: “A atividade econômica em sentido amplo é gênero que compreende duas espécies, o serviço público e a atividade econômica em sentido estrito, empreendida por agentes econômicos privados. [...]" (BRASIL, 


\section{O REGIME JURÍDICO DAS EMPRESAS ESTATAIS SOB A ÓTICA DA LEI N.13.303/2016: ASPECTOS GERAIS, ESPECÍFICOS E POLÊMICOS}

2010b).

Oliveira (2016) vai além e defende que há as empresas que prestam serviços públicos e as que os prestam simultaneamente com a exploração de atividades econômicas em sentido estrito, como, por exemplo, a Empresa Brasileira de Correios e Telégrafos (OLIVEIRA, Rafael 2016).

Para Pereira (2016), o Estatuto Jurídico das Empresas Estatais incide apenas sobre as empresas que prestem serviços públicos com características de exploração de atividade econômica em sentido estrito, excluindo-se as prestadoras de serviços públicos que atuam em ambiente não competitivo.

Contudo, mais adequado é o entendimento de que o art. $1^{\circ}$ da Lei n. 13.303/2016 abrange toda e qualquer empresa pública e sociedade de economia mista, inclusive as que prestam serviços públicos. Parece que, ao se incluir no âmbito de aplicação da lei até mesmo as empresas estatais que atuam em regime de monopólio, não se pretendeu restringir sua aplicação àquelas que atuam apenas em ambiente competitivo.

Ademais, ao optar por uma sociedade empresarial para a prestação de serviços públicos, a Administração Pública pretendeu, com amparo nas finalidades que se desejou alcançar ao constituí-la, sujeitá-la a regime jurídico semelhante ao do setor privado (DI PIETRO, 2014).

Se, conforme defende Pereira (2016), não é aconselhável submeter a um único regime as empresas estatais prestadoras de serviços públicos e as exploradoras de atividade econômica, eis que são distintas por natureza, a eventual não submissão das estatais prestadoras de serviços públicos à Lei n. 13.303/2016 as manteria no limbo jurídico até então existente ou as forçaria a seguir as normas gerais de licitação estatuídas na Lei n.8. 666/1993, frustrando por completo a intenção da Administração em criá-las. Não parece ter sido esse o sentido da lei em comento.

Assentado que a Lei n. 13.303/16 abrange todas as empresas públicas e sociedades de economia mista exploradoras de atividade econômica em sentido estrito, em regime concorrencial ou não, e as prestadoras de serviço público, passa-se à análise do regime jurídico a elas aplicável. 


\title{
3 O REGIME JURÍDICO DAS EMPRESAS ESTATAIS ESTABELECIDO PELA LEI
}

\section{N. 13.303/2016}

A Lei n. 13.303/2016 dispõe, entre outros, sobre a sujeição das empresas estatais ao regime jurídico próprio das empresas privadas e sobre o regime de licitações e contratações, nos termos determinados pelo art. $173, \S 1^{\circ}$, da CRFB/1988, com redação dada pela EC n. 19/1998. Às normas de licitações e contratos, a lei ordinária dedicou dois específicos capítulos; porém, quanto ao regime jurídico próprio das empresas privadas, não o fez de modo particular, mas esparsamente.

Compartilha desse entendimento Dias (2016) ao esclarecer que:

\begin{abstract}
A Lei ${ }^{\circ} 13.303 / 2016$, neste aspecto, poderia ter previsto de maneira mais explícita, os elementos descritos no inciso II, do $\S 1^{\circ}$, do art. 173 da CR/1988 acima transcrito. A definição deste regime próprio, entretanto, é depreendida da lei, a partir do momento em que, ao estabelecer as especificidades que afetam regras de direito privado (notadamente quanto ao regime societário dessas empresas) e as derrogações de direito público (notadamente no tocante às licitações e contratos), o conteúdo do regime remanescente das empresas estatais exploradoras de atividades econômicas fica sendo predominantemente privado quanto aos direitos e obrigações civis, comerciais, trabalhistas e tributários. (DIAS, 2016).
\end{abstract}

A adoção do regime jurídico das empresas privadas às empresas estatais extrai-se da leitura contextualizada e sistemática da lei, iniciando-se pelo $\S 2^{\circ}$, do art. $8^{\circ}$, que trata como exceção a assunção de obrigações e responsabilidades pelas empresas estatais em condições distintas daquelas próprias do setor privado. Conclui-se, por lógica, que a regra é justamente a sujeição das empresas públicas e sociedades de economia mista ao regime jurídico próprio das empresas da iniciativa privada.

Se em regimes de Direito Público, como o da Lei n. 8.666/93, as disposições de Direito Privado se aplicam apenas supletivamente, conforme dispõe o art. 54, na Lei n.13.303/2016 a lógica se inverte: aplicam-se, em regra, os preceitos de Direito Privado (art. 68), observados os princípios da Administração Pública.

Mas a questão não é simples e não se encerra com a mera determinação legal e abstrata de que as empresas estatais sujeitam-se a regime jurídico de Direito Privado. Nas palavras de Mello (2015):

É preciso, pois, aturado precato para não incorrer no equívoco de assumir fetichisticamente a personalidade de Direito Privado (como costumada ocorrer no Brasil) das estatais e imaginar que, por força dela, seu regime pode ensejar-lhes uma 
desenvoltura equivalente à dos sujeitos cujo modelo tipológico inspirou-lhes a criação. Deveras, a personalidade de Direito Privado que as reveste não passa de um expediente técnico cujo préstimo adscreve-se, inevitavelmente, a certos limites, que já que não poderia ter o condão de embargar a positividade de certos princípios e normas de Direito Público cujo arrendamento comprometeria objetivos celulares do Estado de Direito. (MELLO, 2015, p. 199).

Diversas regras contidas na Lei n. 13.303/2016 reabrem essa discussão, pois ora prevalecem regras de Direito Privado, ora de Direito Público. Passa-se à análise desses dispositivos.

\subsection{A responsabilidade civil do controlador da empresa estatal}

O art. 15 da Lei n. 13.303/2016 dispôs: "O acionista controlador da empresa pública e da sociedade de economia mista responderá pelos atos praticados com abuso de poder" (BRASIL, 2016). A redação praticamente repete o conteúdo do art. 117 da Lei n. 6.404/1976, que dispõe sobre as sociedades por ações.

Nos termos do art. 116 da Lei das S/A, entende-se por controlador a pessoa natural ou jurídica que, simultaneamente: i) seja titular de direitos de sócio que lhe assegure, de modo permanente, a maioria dos votos nas deliberações da assembleia geral e o poder de eleger a maioria dos administradores da companhia; e ii) utilize efetivamente seu poder para dirigir as atividades sociais e orientar o funcionamento dos órgãos da companhia.

No caso da empresa pública, somente pode ser controlador a União, os Estados, o Distrito Federal ou os Municípios, por força do disposto no art. $3^{\circ}$ da Lei n.13.303/2016. Já a sociedade de economia mista pode ser controlada pelos mesmos entes já citados, além de entidades da Administração indireta, detentora de mais de 50\% (cinquenta por cento) das ações com direito a voto, no caso das subsidiárias, conforme estabelece o art. $4^{\circ}$ da mesma lei.

$\mathrm{O} \S 1^{\circ}$, do art. $4^{\circ}$, do Estatuto das Empresas Estatais, ainda estabelece que "A pessoa jurídica que controla a sociedade de economia mista tem os deveres e as responsabilidades do acionista controlador, estabelecidos na Lei $\mathrm{n}^{\circ}$ 6.404, de 15 de dezembro de 1976 [...]". (BRASIL, 2016).

A figura do acionista controlador não se confunde, portanto, com a dos administradores, que são, por definição do parágrafo único, do art. 16, da Lei n.13.303/2016, os membros do Conselho de Administração e os diretores.

A Lei n.13.303/2016 trata expressamente da responsabilidade civil do controlador das empresas estatais da mesma forma prevista na Lei das S/A no que tange à 
responsabilidade do controlador das empresas privadas.

$\mathrm{O}$ acionista controlador das S/A responde independentemente de culpa pelos atos de abuso de poder. Assim se posiciona Carvalhosa (2003):

Tal como no direito de voto, também o abuso de poder de controle não deve ser psicologicamente perquirido, na medida em que dificilmente se pode configurar, na espécie, intenção subjetiva do agente. Trata-se, com efeito, de prova diabólica, cuja exigência como requisito para configurar a infração seria um obstáculo aos objetivos colimados pela lei,

Deve, e consequência, abandonar o requisito do intuito para deter-se ao exame da conduta, indagando se é prejudicial ao interesse público e ao interesse social, comparando-se com padrões de comportamento geralmente aceitos em situações semelhantes.

[...]

Trata-se, com efeito, de matéria de ordem pública, em que as considerações de ordem moral da conduta devem subsidiar, se possível, o convencimento do dano jurídico e não se prestar a reparação material do dano sofrido pela comunidade ou pelos acionistas, em decorrência dos atos praticados pelo controlador.

Consequentemente, o elemento intencional do ato ou do fato atribuído ao controlador, ainda que figure na letra de lei, não pode sobrepor-se ao elemento material consistente no prejuízo efetivo sofrido pelas pessoas e instituições relacionadas com a companhia. (CARVALHOSA, 2003, p. 507-508).

No mesmo sentido entendeu o Superior Tribunal de Justiça (STJ), no julgamento do REsp n. 10.836/SP:

Contudo, para a caracterização do abuso de poder de que trata o art. 117 da Lei das Sociedades por ações, ainda que desnecessária a prova da intenção subjetiva do acionista controlador em prejudicar a companhia ou os minoritários (cfr. Modesto Carvalhosa, op. cit., p. 507), é indispensável a prova do dano, na esteira de precedente da 3. a Turma, relatado pelo Min. Cláudio Santos. (BRASIL apud BRASIL, Resp. 798.264/SP, 2007).

Apesar de no regime da Lei das S/A e da Lei n.13.303/2016 o controlador responder objetivamente pelos atos de abuso de poder, há entre os dois diplomas normativos substancial distinção que não deve passar despercebida. Trata-se do $\S 1^{\circ}$, do art. 15 , da Lei das estatais, o qual estabelece que "a ação de reparação poderá ser proposta pela sociedade, nos termos do art. 246 da Lei no 6.404, de 15 de dezembro de 1976, pelo terceiro prejudicado ou pelos demais sócios, independentemente de autorização da assembleia-geral de acionistas". (BRASIL, 2016).

Ao tratar da propositura da ação de reparação pela sociedade (empresa estatal) contra o controlador, a Lei n. 13.303/2016 expressamente remete ao art. 246 da Lei das S/A, que estabelece que a ação será promovida pelos acionistas que representem cinco por cento ou mais do capital social ou por qualquer acionista que prestar caução. 


\title{
O REGIME JURÍDICO DAS EMPRESAS ESTATAIS SOB A ÓTICA DA LEI N.13.303/2016: ASPECTOS GERAIS, ESPECÍFICOS E POLÊMICOS
}

Inova, contudo, ao atribuir ao terceiro prejudicado e aos demais sócios a legitimidade ativa para reclamar indenização pelo ato de abuso de poder que cause danos. Segundo Nester (2016, p. 137) “a partir da Lei n.13.303/2016, a legitimidade ativa dos minoritários, e de terceiros prejudicados, é expressa”.

E é exatamente essa inovação, ainda que meramente textual ${ }^{3}$, especialmente quanto ao terceiro prejudicado, que reacende a discussão sobre a responsabilidade civil do acionista controlador das empresas estatais.

Não há dúvida de que as condutas ilícitas praticadas no âmbito das empresas estatais, cuja criação somente pode se dar para o atendimento do interesse coletivo ou imperativo da segurança nacional, ofende interesses jurídicos muito mais amplos que os meramente privados. Nesse sentido, pontua Nester (2016):

\begin{abstract}
Em se tratando de uma empresa estatal, portanto, a fiscalização do abuso de poder de controle demanda um grau de preocupação mais elevado, pois as consequências do abuso atingem um universo de interesses mais complexo e mais amplo que, normalmente, ocorre com qualquer sociedade anônima. (NESTER, 2016, p. 139).
\end{abstract}

Daí que, embora se perceba na Lei n. 13.303/2016 ligação com a Lei 6.404/76, de caráter privado, ao ampliar a legitimação para agir contra o abuso de poder do ente estatal controlador, a norma assume caráter evidentemente publicista.

Desse modo, ao atribuir a terceiros a legitimação ativa da ação de reparação de danos que a Lei das S/A atribuía unicamente à sociedade, por meio de seus acionistas, a responsabilidade civil do controlador da empresa pública ou sociedade de economia mista, Estado que é, também passa a encontrar fundamento nas regras eminentemente publicistas do art. $37, \S 6^{\circ}$, da CRFB $/ 1988^{4}$, e do art. 43, do Código Civil de $2002^{5}$.

Logo, a responsabilidade do controlador das empresas estatais será objetiva assim como a do Estado em geral; agora, contudo, essa fundamenta-se não só nas normas de Direito Privado da Lei das S/A, mas também nas normas de Direito Público presentes na Constituição da República e no Código Civil.

\footnotetext{
${ }^{3}$ Embora não constante da redação da Lei das S/A, Nester (2016), na obra citada, reconhece a legitimidade ativa dos acionistas minoritários e de terceiros contra o controlador com base no princípio do acesso à justiça, previsto no art. $5^{\circ}$, inc. XXXV, da Constituição de 1988, e no art. $4^{\circ}$, da Lei de Introdução ao Código Civil.

${ }^{4} \S 6^{\circ}$ As pessoas jurídicas de direito público e as de direito privado prestadoras de serviços públicos responderão pelos danos que seus agentes, nessa qualidade, causarem a terceiros, assegurado o direito de regresso contra o responsável nos casos de dolo ou culpa. (BRASIL, 1988).

${ }^{5}$ Art. 43. As pessoas jurídicas de direito público interno são civilmente responsáveis por atos dos seus agentes que nessa qualidade causem danos a terceiros, ressalvado direito regressivo contra os causadores do dano, se houver, por parte destes, culpa ou dolo. (BRASIL, 2002).
} 
3.2Os critérios de nomeação para diretores e membros do Conselho de Administração

Outra disposição da Lei n. 13.303/2016 fundada em regras de Direito Público é a prevista no art.17, que estabelece diversos requisitos pessoais para o desempenho da função de administrador das estatais.

O objetivo de tais exigências, nas palavras de Oliveira (2016), é "diminuir ou mesmo neutralizar a influência política sobre a indicação dos conselheiros e diretores nas empresas estatais", o que se torna ainda mais claro considerado o momento político da entrada em vigor da Lei das Estatais. (OLIVEIRA, Fernão, 2016, p. 150).

Dentre esses requisitos, está o que veda a participação de pessoas inelegíveis na administração da empresa estatal, conforme art. 17, inc. III, da Lei n. 13.303/2016. Trata-se de restrições às pessoas sem as condições de elegibilidade estabelecidas pela Lei Complementar n. 64/1990 (BRASIL, 1990), com as alterações da Lei Complementar n. 135/2010 (BRASIL, 2010a), denominada Lei da Ficha Limpa. Dentre os casos de inelegibilidade na citada lei complementar, encontra-se, por exemplo, o estabelecido no art. $1^{\circ}$, inciso I, alínea $g$, que tornou inelegíveis para qualquer cargo "os que tiverem suas contas relativas ao exercício de cargos ou funções públicas rejeitadas por irregularidade insanável que configure ato doloso de improbidade administrativa[...]” (BRASIL, 2010a).

A norma, assim como outras previstas na Lei da Ficha Limpa, é nitidamente de Direito Público, transpostas para o regime das empresas estatais, submetidas, em regra, a regime de Direito Privado.

\subsection{Das licitações e contratos e da aplicação da Lei n. 8.666/1993}

A redação original da CRFB/1988 não fazia nenhuma ressalva quanto à aplicação de regras diferenciadas de licitações e contratos administrativos para empresas públicas e sociedades de economia mista.

Segundo Justen Filho (2016, p. 284), “toda a atividade contratual da Administração Pública, inclusive da Administração indireta com personalidade jurídica de direito privado, subordinava-se à regra do art. 37, XXI, da CF/1988”. Por isso mesmo, a Lei n. 8.666/1993, no art. $1^{\circ}$, parágrafo único, dispôs que as empresas públicas e sociedades de economia mista subordinavam-se às suas normas.

Foi a Emenda Constitucional n 19/1998 que, ao alterar a redação do art. 22, inc. 
XXVII, limitou a aplicação das normas gerais de licitação e contratação às "administrações públicas diretas, autárquicas e fundacionais da União, Estados, Distrito Federal e Municípios" (BRASIL, 1998), sujeitando as empresas estatais a regime próprio, nos termos do art. 173, $\S$ $1^{\circ}$, da CRFB/1988.

Portanto, embora a evolução normativa tenha caminhado no único sentido possível, de que as regras para a Administração Pública direta, autárquica e fundacional devem ser distintas e das aplicáveis às empresas estatais, manteve-se a obrigação de estas observarem os princípios gerais da Administração Pública.

Ainda segundo Justen Filho (2016, p. 288), “a disciplina da Lei 13.303/2016 foi altamente influenciada pela Lei 8.666 e pela jurisprudência do TCU. O grande desafio reside em interpretar e aplicar os dispositivos segundo uma principiologia autônoma."

Apesar disso, a regência da Lei n. 8.666/1993 nas empresas estatais foi quase completamente afastada por força do art. 41 da Lei n. 13.303/2016, mantendo-se aplicáveis apenas as disposições de Direito Penal previstas nos art. 89 a 99 da Lei Geral.

\title{
3.3.1 O regime jurídico aplicável aos contratos relacionados às atividades-fim
}

Mesmo antes do advento da Lei n. 13.303/2016, a jurisprudência do Tribunal de Contas da União (TCU) já havia se consolidado no sentido de que as empresas estatais não se submetiam necessariamente às regras de licitação no exercício de suas atividades-fim ${ }^{6}$. Esclarece Pereira (2016):

\begin{abstract}
A discussão surgiu até mesmo antes da EC 19/1998, tendo em vista o manual de contratações adotado pela Petrobras na época. No Acórdão nº 121-1998, o Plenário do TCU afirmou a desnecessidade de realização de licitação para as atividades-fim das empresas estatais que exploram atividade econômica. O caso foi decidido ainda à luz da redação original do art. 173. Reputou-se que a agilidade nessas contratações seria necessária nos casos relativos a 'procedimentos usuais de mercado em que atua e indispensáveis ao desenvolvimento de sua atividade normal'. (PEREIRA, 2016, p. 334).
\end{abstract}

A Lei n. 13.303/2016 consolidou esse entendimento no art. $28, \S 3^{\circ}$, inciso I, ao dispensar as empresas estatais de licitar quando se tratar de "comercialização, prestação ou execução, de forma direta, pelas empresas mencionadas no caput, de produtos, serviços ou

\footnotetext{
${ }^{6}$ Nesse sentido, vide Acórdão n. 121/1998-Plenário (BRASIL, 1998) Acórdão n. 624/2003-Plenário (BRASIL, 2003a), Acórdão n. 1.581/2003-Plenário (BRASIL, 2003b) (Acórdão n. 403/2004-Plenário (BRASIL, 2004a), Acórdão 1.390/2004-Plenário (BRASIL, 2004b).
} 
obras especificamente relacionados com seus respectivos objetos sociais" (BRASIL, 2016).

Não se exclui, mesmo nessas ocasiões, a necessidade de observância de princípios da administração, especialmente o da impessoalidade. É indubitável, contudo, que no exercício das atividades-fim, as contratações se realizam quase que exclusivamente no campo do Direito Privado, com pouquíssima influência de normas de Direito Público.

Mas, quando as contratações se concretizam no exercício das chamadas atividadesmeio das empresas públicas e sociedades de economia mista, prevalecem normas de Direito Público.

\subsubsection{O regime jurídico aplicável aos contratos relacionados às atividades-meio}

Quando se fala em licitação, fala-se em Direito Público. Isso porque, nos dizeres de Mello (2015),

Ao contrário dos particulares, que dispõem de ampla liberdade quando pretendem adquirir, alienar, locar bens, contratar a execução de obras ou serviços, o Poder Público, para fazê-lo, necessita adotar um procedimento preliminar rigorosamente determinado e preestabelecido na forma da lei. Tal procedimento denomina-se licitação. (MELLO, 2015, p. 536).

Di Pietro (2014, p. 373), na mesma direção, diz que "Ao falar-se em procedimento administrativo, está-se fazendo referência a uma série de atos preparatórios do ato final objetivado pela Administração."

Logo, na medida em que a CRFB/1988 e a Lei n. 13.303/2016 estabelecem a obrigatoriedade de as empresas estatais submeterem-se a regras de licitações e contratações, necessariamente se está a tratar de regime predominantemente de Direito Público.

A Lei n. 13.303/2016, nesse particular, flexibiliza o procedimento licitatório aproximando-o das práticas de contratações adotadas no âmbito da iniciativa privada. Justen Filho (2016) defende essa disciplina mais flexível nos seguintes termos:

A disciplina das licitações e contratações das empresas estatais exploradoras de atividade econômica deve ser compatível com as práticas de mercado. Mesmo aquelas relações jurídicas não relacionadas diretamente com a atividade central da empresa, que configura o seu objeto social, deve ser subordinada a regime jurídico menos formalista. Assim, suponha-se o exemplo de contratações relacionadas com o desenvolvimento de novos produtos, com programas de comunicação social e com a obtenção de insumos para produtos e serviços, as quais devem ser compatíveis com as práticas adotadas de modo genérico pelas demais empresas que atuam no mesmo setor. (JUSTEN FILHO, 2016, p. 287). 


\section{O REGIME JURÍDICO DAS EMPRESAS ESTATAIS SOB A ÓTICA DA LEI N.13.303/2016: ASPECTOS GERAIS, ESPECÍFICOS E POLÊMICOS}

Nesse sentido, a Lei n. 13.303/2016 abrandou o rigor das regras de licitação contidas na Lei n. 8.666/1993. Cite-se, por exemplo, a dispensa de licitação em virtude do valor do objeto que se quer contratar. A Lei n. 8.666/1993 fixa em 10\% do valor do convite para compra e do valor do convite para contratação de obras e serviços de engenharia, $\mathrm{R} \$$ $80.000,00$ e R \$ 150.000,00 respectivamente. Aplicando-se o percentual, têm-se os valores de R\$ 8.000,00 e R\$ 15.000,00. Já o art. 29, § 3º, da Lei das Empresas Estatais eleva os limites para compra e contratação de obras ou serviços de engenharia sem licitação para $\mathrm{R} \$$ $50.000,00$ e $\mathrm{R} \$ 100.000,00$, respectivamente. Esses valores podem ser alterados por deliberação do Conselho de Administração da estatal, para refletir a variação de custos, admitindo-se valores diferenciados para cada sociedade, enquanto que os previstos na Lei n. $8.666 / 1993$ podem ser alterados somente por meio de lei.

Também o art. 31 da mesma lei estatutária estabelece que, dentre as finalidades da licitação, a seleção da proposta mais vantajosa abrange o elemento "ciclo de vida do objeto", e não somente o seu custo imediato. Pereira argumenta que "A consagração desse conceito entre as finalidades essenciais do processo licitatório das empresas estatais permite a modulação das condições da licitação para que se realize de modo integral os princípios da economicidade e eficiência.” (PEREIRA, 2016, p. 339).

O princípio da eficiência, aliás, foi incluído no art. 37, caput, da CRFB/1988, por força da EC n. 19/1998, embora já estivesse presente no ordenamento jurídico pelo Decretolei n. 200/1967 (FARIA, 2015). Contudo, o referido princípio é originário da ciência da Administração, segundo Di Pietro (2014). ${ }^{7}$

No art. 45, a Lei n. 13.303/2016 ainda prevê a possibilidade de ser estabelecida remuneração variável vinculada ao desempenho do contratado, com base em metas, padrões de qualidade, critérios de sustentabilidade ambiental e prazos de entrega.

Mencione-se, também, a "avaliação de desempenho contratual prévio dos licitantes" como um critério de desempate entre as propostas classificadas em primeiro lugar, conforme disposto no art. 55, inc. II, da Lei das Estatais ${ }^{8}$.

$\mathrm{O}$ art. 71 da Lei n. 13.303/2016 ainda permite a celebração de contratos por prazo

\footnotetext{
${ }^{7}$ Di Pietro explica, citando Jesus Leguina Villa (1995, p.637), que o princípio da eficiência na Administração Pública, embora "pregado pela ciência da Administração", não se confunde com a eficiência do setor privado e nem pode se sobrepor aos demais princípios da Administração, especialmente ao da legalidade (VILLA apud DI PIETRO, p. 84-85, 2014).

${ }^{8} \mathrm{O}$ mencionado dispositivo legal encontra similitude no art. 25, inciso II, da Lei n. 12.462/2011, que disciplina o Regime Diferenciado de Contratações Públicas. (BRASIL, 2011a).
} 
superior a cinco anos, nos casos de projetos contemplados no plano de negócios e investimentos da empresa ou em que a pactuação por prazo superior seja prática rotineira de mercado e a imposição desse prazo inviabilize ou onere excessivamente a realização do negócio.

Ressalte-se, ainda, o art. 72 da lei em comento, o qual estipula que "Os contratos regidos por esta Lei somente poderão ser alterados por acordo entre as partes”. (BRASIL, 2016). A referida regra é inovação legislativa e difere do disposto no art. 65, inc. I, da Lei n. 8.666/1993, que prevê a hipótese de alteração unilateral do contrato pela Administração Pública contratante 9 .

O mencionado art. 72 estabelece, pois, relação de horizontalidade entre a empresa estatal e o particular, retirando daquela uma prerrogativa conferida pela lei geral à Administração Pública.

Enfim, em diversas oportunidades o Estatuto Jurídico das Empresas Estatais aproxima as licitações dos procedimentos de contratação comumente adotados no setor privado.

Em sentido oposto, porém, muitas vezes a Lei n. 13.303/2016 pende para regime mais publicista e menos privatista.

É o caso, por exemplo, da adoção nas licitações das empresas estatais, o regime mais benéfico conferido às micro e pequenas empresas, estabelecido pela Lei Complementar (LC) 123/2006 (BRASIL, 2006), alterada pela Lei Complementar 147/2014 (BRASIL, 2014), conforme art. $28, \S 1^{\circ}$, da Lei n. 13.303/2016.

A preferência estabelecida pela LC n. 123/2006 às estatais é alvo de críticas feitas por Justen Filho (2016), que, após admitir a utilização do instituto como decorrente de um juízo político para a Administração Pública direta, autárquica e fundacional, diz que não é adequado aplicá-lo às estatais, pois:

compromete a exigência de eficiência, eis que a empresa estatal é constrangida a pagar valores superiores aos que poderia obter no mercado pelos mesmos produtos e serviços. Isso se traduzirá em redução de sua capacidade competitiva. Assim se passará porque os seus competidores não se subordinarão a idêntico regime e poderão contratar bens e serviços pelo menor preço possível. (JUSTEN FILHO, 2016, p. 296).

\footnotetext{
9 Para Lefèvre e Wladeck (2016, p. 514), as prerrogativas de alteração unilateral dos contratos pela Administração Pública "já não eram aplicáveis aos contratos das empresas públicas, sociedade de economia mista e suas subsidiárias”.
} 
Nesse sentido, a utilização das licitações das empresas estatais para o alcance de finalidades e resultados mediatos ou indiretos, tais como a proteção às micro e pequenas empresas, muito comuns no regime geral, redireciona o regime jurídico das estatais para o Direito Público.

A prevalência do interesse público sobre o privado também está presente na Lei n. 13.303/2016, ao estabelecer a prerrogativa das empresas estatais de punirem os contratados com advertência, multa e suspensão temporária do direito de licitar e de contratar com a entidade sancionadora, sanções essas previstas no art. 83.

Isso porque o direito de punir da Administração decorre exatamente da condição de prevalência do interesse público em relação ao privado. Conforme ensina Pereira (2016):

\footnotetext{
A possibilidade de imposição de penalidades contratuais pela Administração Pública é uma característica típica dos contratos administrativos (cf. art. 58, IV, da Lei 8.666/1993). O contratante público vale-se de suas competências próprias para apurar infrações e aplicar as sanções cabíveis. (PEREIRA, 2016, p. 529
}

Em outra situação, que se pode considerar até mesmo inusitada, a Lei n. 13.303/2016 não só se aproximou do sistema de Direito Público, como até mesmo extrapolou o rigor da Lei n. 8.666/1993, ao atribuir responsabilidade objetiva ao contratado pelos danos que causar a terceiros ou à empresa contratante na execução do contrato, conforme prescreve o art. 76.

Até mesmo a Lei n. 8.666/1993, de caráter eminentemente público e que impõe nítida relação de verticalidade entre a Administração Pública e o particular, estabelece, no art. 70, relação mais paritária quanto à responsabilidade do contratado, que somente responderá pelos danos que causar se agir com culpa ou dolo.

Orienta-se da mesma forma Justen Filho (2012), ao defender que, no âmbito da Lei n. 8.666/1993, o particular somente será civilmente responsabilizado perante a Administração se agir com culpa ou dolo, tal como acontece, em regra, no Direito Privado.

Sabe-se que a regra é a da responsabilidade civil subjetiva, seja ela contratual ou extracontratual. Especificamente quanto à espécie contratual, o Código Civil prevê, nos art. 389 e 393, que o devedor será civilmente responsável se não cumprir a obrigação que lhe cabe, salvo se o descumprimento decorrer de caso fortuito ou força maior.

A responsabilidade civil objetiva por danos contratuais está excepcionalmente prevista no ordenamento jurídico brasileiro, no art. 12 e no art. 13 do Código de Defesa do Consumidor; os fundamentos dessa espécie de responsabilização, contudo, não têm relação com os contratos celebrados pelas empresas públicas no exercício de suas atividades 
econômicas em sentido amplo (MARQUES; BENJAMIN; MIRAGEM, 2006). ${ }^{10}$

Ora, se o art. 68 da Lei n. 13.303/2016 determina que os contratos celebrados pelas empresas estatais se regulam pelos preceitos de Direito Privado, cuja regra é a da responsabilidade subjetiva, e não se tratando de relação de consumo, o único fundamento que se vislumbra para a responsabilidade objetiva do particular pelos danos que causar durante a execução do contrato é a prevalência do interesse público, representado pela empresa estatal, sobre o privado, representado pelo contratado.

Daí, também, nesse caso específico a Lei n. 13.303/2016 afasta-se do regime próprio de Direito Privado e assume nítida roupagem publicista, em que a empresa pública ou a sociedade de economia mista, embora em regra atue em condição de paridade com os demais agentes do domínio econômico, situa-se em excepcional posição de verticalidade em relação ao particular que com ela contrata.

Outro dispositivo legal de natureza eminentemente pública é o art. $77, \S 1^{\circ}$, da lei em foco, que repete ipsis litteris o art. 71, da Lei n. 8.666/1993, no sentido de que a empresa pública e as sociedades de economia mista não respondem pela inadimplência do contratado, quanto aos encargos trabalhistas, fiscais e comerciais por ele assumidos.

Diversamente, no setor privado, especificamente quanto às obrigações trabalhistas, a inadimplência do contratado "implica a responsabilidade subsidiária do tomador dos serviços quanto àquelas obrigações”, nos termos da Súmula 331, inciso IV, do TST. (BRASIL, 2011b)

As empresas estatais sujeitam-se, ainda, ao controle interno e externo da Administração Pública direta e indireta (art. 70, CR/1988), e, ainda, à fiscalização da sociedade, nos termos dos art. 85 a 90 da Lei n. 13.303/2016.

\section{CONCLUSÃO}

A despeito de a CRFB/1988 e de a Lei n.13.303/2016 expressamente estabelecerem que as empresas públicas e sociedades de economia mista sujeitam-se ao regime jurídico de Direito Privado, julgou-se necessário refletir sobre o verdadeiro e efetivo alcance das respectivas normas jurídicas.

Relativamente à responsabilidade civil do controlador das empresas estatais, a regra aplicável é eminentemente de Direito Privado, mas também encontra fundamentos na responsabilidade civil do Estado, previstos no at. 37, § $6^{\circ}$, da CRFB/1988, e no art. 43 do

\footnotetext{
${ }^{10}$ Para os autores, o sistema de responsabilidade objetiva presente no CDC foi influenciado pelos sistemas norteamericano e o sistema da Directiva (35/374/CEE, de 25.07.2005), da Comunidade Econômica Europeia.
} 
CC/2002, respectivamente.

Já a pretensão de reduzir a influência política nas nomeações dos administradores e diretores das empresas públicas e sociedades de economia mista impele a Lei n. 13.303/2016 a instituir critérios cuja natureza é de Direito Público.

A fim de preservar a condição de competitividade num ambiente concorrencial, garantiu-se que os processos de aquisição e os contratos celebrados relacionados às atividades-fim das empresas estatais submetem-se quase que exclusivamente às regras praticadas na iniciativa privada, mas não deixa de exigir a observância de princípios típicos do Direito Público.

No que tange às atividades-meio das empresas públicas e sociedades de economia mista, a submissão ao regime de licitações impõe o reconhecimento da prevalência de normas de Direito Público, inclusive aos contratos delas decorrentes. Todavia, é nítida a flexibilização de diversos institutos consolidados na Lei n. 8.666/1993, aproximando-os do que comumente se pratica no âmbito privado.

Portanto, tendo-se em vista a pesquisa realizada e a investigação dos diversos dispositivos legais, conclui-se, por fim, que o regime jurídico estabelecido pela Lei n. 13.303/2016 é híbrido, submetendo as empresas estatais ora ao regime de Direito Público, ora ao de Direito Privado, sendo que tal alternância ocorre de acordo com o bem jurídico pretensamente tutelado pelo Estatuto Jurídico das Empresas Estatais.

\section{REFERÊNCIAS}

BRASIL. Constituição da República Federativa do Brasil de 1988. Brasília: Senado, 1988. Nós, representantes do povo brasileiro, reunidos em Assembléia Nacional Constituinte para instituir um Estado Democrático, destinado a assegurar o exercício dos direitos sociais e individuais, a liberdade, a segurança, o bem-estar, o desenvolvimento, a igualdade e a justiça (...). Diário Oficial da União, Brasília, 5 out. 1988. Disponível em: <http://www.planalto.gov.br/ccivil_03/Constituicao/Constituicao.htm>. Acesso em: 12 jul. 2017.

BRASIL. Decreto-Lei n. 200, de 25 de fevereiro de 1967. Dispõe sobre a organização da Administração Federal, estabelece diretrizes para a Reforma Administrativa e dá outras providências. Diário Oficial da União, Brasília, 27 fev. 1967. Disponível em: <http://www.planalto.gov.br/ccivil_03/decreto-lei/Del0200.htm.> Acesso em: 12 jul. 2017.

BRASIL. Decreto-Lei 2.300 de 21 de novembro de 1986. Dispõe sobre licitações e contratos da Administração Federal e dá outras providências. Diário Oficial da União, Brasília, 25 nov. 1986. Disponível em: <http://www.planalto.gov.br/ccivil_03/decreto-lei/Del230086.htm>. Acesso em: 19 set. 2016. 
BRASIL. Emenda Constitucional n ${ }^{\circ}$ 19, de 4 de junho de 1998. Modifica o regime e dispõe sobre princípios e normas da Administração Pública, servidores e agentes políticos, controle de despesas e finanças públicas e custeio de atividades a cargo do Distrito Federal, e dá outras providências. Diário Oficial da União, Brasília, 5 jun. 1998. Disponível em: <http://www.planalto.gov.br/ccivil_03/Constituicao/Emendas/Emc/emc19.htm> Acesso em: 07 ago. 2017.

BRASIL. Lei Complementar n. 64, de 18 de maio de 1990. Estabelece, de acordo com o art. $14, \S 9^{\circ}$ da Constituição Federal, casos de inelegibilidade, prazos de cessação, e determina outras providências. Diário Oficial da União, Brasília, 21 maio 1990. Disponível em: <http://www.planalto.gov.br/ccivil_03/leis/lcp/lcp64.htm> Acesso em: 12 jul. 2017.

BRASIL. Lei Complementar $\mathrm{n}^{\circ} 123$, de 14 de dezembro de 2006. Institui o Estatuto Nacional da Microempresa e da Empresa de Pequeno Porte; altera dispositivos das Leis no 8.212 e 8.213, ambas de 24 de julho de 1991, da Consolidação das Leis do Trabalho - CLT, aprovada pelo Decreto-Lei no 5.452, de 1o de maio de 1943 (...). Diário Oficial da União, Brasília, 15 dez. 2006. Disponível em: 〈http://www.planalto.gov.br/ccivil_03/leis/LCP/Lcp123.htm> Acesso em: 12 jul. 2017.

BRASIL. Lei Complementar n. 135, de 04 de junho de 2010. Altera a Lei Complementar n. 64, de 18 de maio de 1990, que estabelece, de acordo com o $\S 9^{\circ}$ do art. 14 da Constituição Federal, casos de inelegibilidade, prazos de cessação e determina outras providências, para incluir hipóteses de inelegibilidade que visam a proteger a probidade administrativa e a moralidade no exercício do mandato. Diário Oficial da União, Brasília, 7 jun. 2010a. Disponível em: <http://www.planalto.gov.br/ccivil_03/leis/lcp/Lcp135.htm\#art2.> Acesso em: 12 jul. 2017.

BRASIL. Lei Complementar n. 147, de 7 de agosto de 2014. Altera a Lei Complementar no 123, de 14 de dezembro de 2006, e as Leis nos 5.889, de 8 de junho de 1973, 11.101, de 9 de fevereiro de 2005, 9.099, de 26 de setembro de 1995, 11.598, de 3 de dezembro de 2007, 8.934, de 18 de novembro de 1994, 10.406, de 10 de janeiro de 2002, e 8.666, de 21 de junho de 1993; e dá outras providências. Diário Oficial da União, Brasília, 8 ago. 2014. Disponível em: <http://www.planalto.gov.br/ccivil_03/leis/LCP/Lcp147.htm>Acesso em: 13 jul. 2017.

BRASIL. Lei n. 6.404, de 15 de setembro de 1976. Dispõe sobre as Sociedades por Ações. Diário Oficial da União, Brasília, 17 dez. 1976. Disponível em:

<http://www.planalto.gov.br/ccivil_03/leis/L6404consol.htm> Acesso em: 12 jul. 2017.

BRASIL. Lei n. 8.666 de 21 de junho de 1993. Regulamenta o art. 37, inciso XXI, da Constituição Federal, institui normas para licitações e contratos da Administração Pública e dá outras providências. Diário Oficial da União, Brasília, 22 jun. 1993. Disponível em: <http://www.planalto.gov.br/ccivil_03/leis/18666compilado.htm> Acesso em: 12 jul. 2017.

BRASIL. Lei n. 10.406, de 10 de janeiro de 2002. Institui o Código Civil. Diário Oficial da União. Brasília, 11 jan. 2002. Disponível em: <http://www.planalto.gov.br/ccivil_03/LEIS/2002/L10406.htm>. Acesso em: 7 ago. 2017.

BRASIL. Lei Federal n. 12.462, de 04 de agosto de 2011. Institui o Regime Diferenciado de Contratações Públicas - RDC; altera a Lei no 10.683, de 28 de maio de 2003, que dispõe 
sobre a organização da Presidência da República e dos Ministérios, a legislação da Agência Nacional de Aviação Civil (Anac) e a legislação da Empresa Brasileira de Infraestrutura Aeroportuária (Infraero); (...). Diário Oficial da União, Brasília, 5 ago. 2011a. Disponível em: <http://www.planalto.gov.br/ccivil_03/_ato2011-2014/2011/lei/112462.htm> Acesso em: 12 jul. 2017.

BRASIL. Lei Federal n. 13.303, de 30 de junho de 2016. Dispõe sobre o estatuto jurídico da empresa pública, da sociedade de economia mista e de suas subsidiárias, no âmbito da União, dos Estados, do Distrito Federal e dos Municípios. Diário Oficial da União, Brasília, 01 jul. 2016. Disponível em: <http://www.planalto.gov.br/ccivil_03/_ato20152018/2016/lei/l13303.htm> Acesso em: 12 jul. 2017.

BRASIL. Supremo Tribunal Federal. Ação por Descumprimento de Preceito Fundamental n. 46/DF, Relator para o acórdão: Ministro Marco Aurélio. Diário da Justiça Eletrônico no 35, Brasília, 26 fev. $2010 b$.

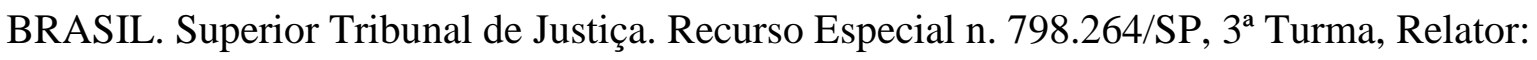
Min. Carlos Alberto Menezes de Direito, Relatora para o acórdão: Min. Nancy Andrighi.

Diário da Justiça Eletrônico, Brasília, 16 abr. 2007. 16.04.2007. Disponível em: $<$ http://mariacelesteadv.com.br/wp-content/uploads/2014/05/Recurso-Especial-Nr.-798..264SP-2005-0190864-1.pdf> Acesso em: 12 jul. 2017.

BRASIL. Tribunal de Contas da União. Acórdão 121/1998 - Plenário. Brasília: TCU, 1998, Disponível em:

<http://www.tcu.gov.br/Consultas/Juris/Docs/judoc\%5CSIDOC\%5CgeradoSIDOC_AC01213 598P.pdf> Acesso em: 12 jul. 2017.

BRASIL. Tribunal de Contas da União. Acórdão n. 403/2004-Plenário. Brasília: TCU, 2004a. Disponível em:

<https://contas.tcu.gov.br/juris/SvlHighLight?key=41434f5244414f2d434f4d504c45544f2d31 37393136\&sort=RELEVANCIA\&ordem=DESC\&bases=ACORDAO-

COMPLETO; \&highlight $=\&$ posicaoDocumento $=0 \&$ numDocumento $=1 \&$ totalDocumentos $=1>$ Acesso em: 12 jul. 2017.

BRASIL. Tribunal de Contas da União. Acórdão n. 624/2003-Plenário. Brasília: TCU, 2003a. Disponível em:

<http://www.lexml.gov.br/urn/urn:lex:br:tribunal.contas.uniao;plenario:acordao:2003-0604;624> Acesso em: 12 jul. 2017.

BRASIL. Tribunal de Contas da União. Acórdão 1.390/2004-Plenário. Brasília: TCU, 2004b. Disponível em:

<http://www.tcu.gov.br/Consultas/Juris/Docs/judoc\%5CAcord\%5C20040915\%5CTC\%20006 .244.doc.> Acesso em: 12 jul. 2017.

BRASIL. Tribunal de Contas da União. Acórdão n. 1.581/2003-Plenário. Brasília: TCU, 2003b. Disponível em:

$<$ https://contas.tcu.gov.br/pesquisaJurisprudencia/\#/detalhamento/11/\%252a/NUMACORDA O\%253A1581\%2520ANOACORDAO\%253A2003/DTRELEVANCIA\%2520desc\%252C\%2 520NUMACORDAOINT\%2520desc/false/1/false> Acesso em: 12 jul. 2017. 
BRASIL. Tribunal Superior do Trabalho. Súmula nº 331. Contrato de Prestação de Serviços. Legalidade. (nova redação do item IV e inseridos os itens V e VI à redação). Res. 174/2011, DEJT divulgado em 27, 30 e 31.05.2011. Diário Eletrônico da Justiça do Trabalho, Brasília, 31 maio 2011. Disponível em:

<http://www3.tst.jus.br/jurisprudencia/Sumulas_com_indice/Sumulas_Ind_301_350.html> Acesso em: 7 ago. 2017

CARVALHO FILHO, José dos Santos. Manual de direito administrativo. 28. ed. São Paulo: Atlas, 2015.

CARVALHOSA, Modesto. Comentários à lei de sociedades anônimas: Lei nº 6.404, de 15 de dezembro de 1976, com as modificações das Leis $\mathrm{n}^{\circ}$ 9.457, de 5 de maio de 1997, e ${ }^{\circ}$ 10.303, de 31 de outubro de 2001. São Paulo: Saraiva, 2003. v.2.

DI PIETRO, Maria Sylvia Zanella. Direito administrativo. 27. ed. São Paulo: Atlas, 2014. DIAS, Maria Tereza Fonseca. O Estatuto jurídico das empresas estatais (Lei 13.303/2016) sob a ótica da Constituição da República de 1988. Revista Colunistas de Direito do Estado, n. 223, 2016. Disponível em: < http://www.direitodoestado.com.br/colunistas/maria-terezafonseca-dias/o-estatuto-juridico-das-empresas-estatais-lei-133032016-sob-a-otica-daconstituicao-da-republica-de-1988> Acesso em: 7 ago. 2017.

FARIA, Edimur Ferreira de. Curso de direito administrativo positivo. 8. ed. Belo Horizonte: Fórum, 2015.

FURTADO, Lucas Rocha. Curso de direito administrativo. 4. ed. rev. e atual. Belo Horizonte: Fórum, 2013.

JUSTEN FILHO, Marçal. A contratação sem licitação nas empresas estatais. In: JUSTEN FILHO, Marçal (Org.). Estatuto jurídico das empresas estatais. São Paulo: Revista dos Tribunais, 2016. p. 283-325.

JUSTEN FILHO, Marçal. A Lei 13.303/2016, a criação das empresas estatais e a participação minoritária em empresas privadas. In: JUSTEN FILHO, Marçal (Org.). Estatuto jurídico das empresas estatais. São Paulo: Revista dos Tribunais, 2016. p. 39-57.

JUSTEN FILHO, Marçal. Comentários à Lei de Licitações e Contratos Administrativos. 15. ed. São Paulo: Dialética, 2012.

LEFÈVRE, Mônica Bandeira de Mello; WLADECK, Felipe Scripes. Alteração dos contratos das empresas estatais. In: JUSTEN FILHO, Marçal (Org.). Estatuto jurídico das empresas estatais. São Paulo: Revista dos Tribunais, 2016.

MARQUES, Cláudia Lima; BENJAMIN, Antonio Herman V.; MIRAGEM, Bruno. Comentários ao código de defesa do consumidor. 2. ed. São Paulo: Editora Revista dos Tribunais, 2006.

MEIRELLES, Hely Lopes. Direito administrativo brasileiro. 40. ed. São Paulo: Malheiros, 2014. 
MELLO, Celso Antônio Bandeira de. Curso de direito administrativo. 32. ed. São Paulo: Malheiros, 2015.

NESTER, Alexandre Wagner. O exercício do poder de controle nas empresas estatais. In: JUSTEN FILHO, Marçal (Org.). Estatuto jurídico das empresas estatais. São Paulo: Revista dos Tribunais, 2016. p. 121-138.

OLIVEIRA, Fernão Justen de. Os administradores das empresas estatais. In: JUSTEN FILHO, Marçal (Org.). Estatuto jurídico das empresas estatais. São Paulo: Revista dos Tribunais, 2016. p. 141-167.

OLIVEIRA, Rafael Carvalho Rezende. As licitações na Lei 13.303/2016 (Lei das Estatais): mais do mesmo? Revista Colunistas de Direito do Estado, n. 230. 2016. Disponível em: <http://www.direitodoestado.com.br/colunistas/rafael-carvalho-rezende-oliveira/as-licitacoesna-lei-133032016-lei-das-estatais-mais-do-mesmo> Acesso em: 7 ago. 2017.

PEREIRA, Cesar Augusto Guimarães. Processo licitatório das empresas estatais: finalidades, princípios e disposições gerais. In: JUSTEN FILHO, Marçal (Org.). Estatuto jurídico das empresas estatais. São Paulo: Revista dos Tribunais, 2016. p. 327-351.

PEREIRA, Cesar Augusto Guimarães. Sanções administrativas na Lei das Empresas Estatais. In: JUSTEN FILHO, Marçal (Org.). Estatuto jurídico das empresas estatais. São Paulo: Revista dos Tribunais, 2016. p. 525-563. 